\title{
Technology of the European Corn Borer (Ostrinia nubilalis Hbn) Mass Rearing, Successive Generations, in Controlled Conditions, at NARDI FUNDULEA
}

\author{
Emil GEORGESCU ${ }^{1 *}$, Mariana BURCEA², Lidia CANA ${ }^{1}$, Luxita RASNOVEANU ${ }^{3}$ \\ ${ }^{1}$ Plant Protection Laboratorty, NARDI Fundulea, 1 Nicolae Titulescu Street, 915200, Fundulea, Romania \\ ${ }^{2}$ University of Agricultural Sciences and Veterinary Medicine, Bucharest, 59 Marasti Street, District 1, \\ 011464, Bucharest, Romania \\ ${ }^{3}$ Plant Protection Laboratorty, ARDS Braila, Sos. Viziru-Braila km. 9, 810008, Braila, Romania \\ * corresponding author: emilgeorgescu2013@gmail.com
}

\begin{abstract}
Obtain insects egg batches in laboratory conditions, used for artificial infestation of the maize plants, to establish maize lines and hybrids tolerance to pest attack. Because in nature, the attack of Ostrinia nubilalis are not at same level, every year, as result of the climatic conditions, especially at egg batch deposition and larva emergence, artificial infestation of the maize plants is one of the best method to evaluate maize lines and hybrids reaction at this pest. European corn borer is reared at Plant Protection Laboratory, from NARDI Fundulea, Calarasi County, Romania. Field experiments were made at experimental fields of both, Plant Protection and Maize Breeding laboratories. In 2011 it has obtained 136043 egg batches, in 2012 it has obtained 121945 egg batches and in 2013 it has obtained 133550 egg batches. At the end of the year 2013, the insect colony created in 1979 arrived at 442nd consecutive generation, the insect colony created in 2008 arrived at 77 th consecutive generation, the insect colony created in 2010 arrived at 51st consecutive generation and insect colony created in 2011 arrived at 38th consecutive generation. Even if insects are reared more then 440 generations in laboratory conditions, they don't lose capacity of attacking maize plants. Rearing of the European corn borer (Ostrinia nubilalis Hbn) in laboratory conditions, in continuous flux, on same artificial diet, is one of the best methods for mass production of the eggbatches necessary for the field researches concerning maize hybrids and lines tolerance at the attack produced by this pest.
\end{abstract}

Keywords: diet,insects, laboratory, maize, rearing.

\section{INTRODUCTION}

In last years, European corn borer (Ostrinia nubilalis $\mathrm{Hbn}$ ) area has increasing in some countries from west or south-west of the Europe, such as: France, Germany, Spain, Portugal (Brookes, 2007; Brookes, 2008). Same author mentioned that, in some countries from Central Europe, such as Czech Republic or Slovakia, the area of this pest extend to north. Acording of some studies made in Germany, ECB area extend in north and east of the country (Gathmann and Rothmeier, 2005). Similar studies in Poland, made by Plant Protection Institute from Warsaw and Poznan, arrive at same conclusion, that $O$. nubilalis area extend from south-est to north and east of the country (Beres and Konefal, 2010; Beres, 2012). Recent research made in Hungary, make in evidence that ECB area extend from south-east 
to north-west (Keszthelyi, 2010). A possible cause for area increasing of European corn borer from south to north is climate change such us average air temperature increasing (Kocmánková et al., 2010). Same author mentioned that, as result of the climate changes, this pest present more then one generation/year. Increasing numbers of generations per year in some areas are reported in different countries from Central and West Europe (Brookes, 2008; Derron et al., 2009; Keszthelyi, 2010). O. nubilalis were first time signalised in south-west of England, on maize crops (Korycinska and Cannon, 2010).

In Romania, favourable areas for European corn borer are in west part of the country, Transylvania, hilly areas, along meadows of the main rivers and Danube (Barbulescu et al., 2001). In south and south-east of the country is second pest like economical importance, after Tanymecus dilaticollis (Cristea et. al., 2004). In specialty recent literature it has mentioned that average yield losses in Romania, because of the European corn borer attack arrive at 7,5\%, but in West Plane arrive at $17,7 \%$ and $10,5 \%$ in Transylvania (Popov and Rosca, 2007). In last years, in west part of the Romania and Transylvania it has signalized increasing of the damages produced by European corn borer to maize crops (Alexandri, 2011). The author mentioned that possible causes for ECB attack increasing, climate changes and lack of information about new foreign maize hybrids tolerance to this pest. Malschi et al. (2013) report increasing of the $O$. nubilalis average attack frequency in 2012, at ARDS Turda (Transilvania) and a fly peek in second decade of July. Previous this report, in same region, Ivas and Muresan (2011) mentioned that, higher adults of ECB were cached in pheromone traps, which proves that pest population level increasing in maize crops.

One of the best method for control Ostrinia nubilalis attack is using of maize hybrids with tolerance at this pest (Popov and Barbulescu, 2007). Because in nature, the attack of European corn borer are not at the same level, every year, as result of the climatic conditions variability, especially at egg batch deposition and larva emergence, artificial infestation of the maize plants is one of the best method to evaluate maize lines and hybrids reaction at this pest. $O$. nubilalis is first pest grown in laboratory conditions, on artificial diet (Barbulescu, 1980). In Romania researches concerning mass rearing of the 0 . nubilalis in laboratory conditions starting in years 70 at ICCPT Fundulea (actual NARDI Fundulea) for south of the Romania and ARDS Turda for Transylvania. At NARDI Fundulea it has researched many themes, such as: finding of the better diet for growing of the European corn borer, consecutive generations in laboratory conditions (Barbulescu, 1977, 1980, 1984), influence of the temperature concerning storage time of the egg batches (Barbulescu, 1979), stability of the insects grown consecutive generations on same artificial diet, in laboratory conditions (Barbulescu, 1984, 1986, 1993, 1996, 2001). Egg batches obtained from the moths grown in laboratory conditions were used for artificial infestation of the maize plants for establishment of the inbreed lines and hybrids tolerance for this pest (Barbulescu and Cosmin, 1997; Barbulescu et al., 1999). At ARDS Turda it has researched chemical control of European corn borer (Mustea, 1977; Muresan and Mustea, 1995) or maize hybrid resistence at this pest, in artificial and natural infestation conditions (Mustea, 1981, 1990).

Now days, only at NARDI Fundulea it has continued growing of the European corn borer in laboratory conditions, for obtaining of the egg-batches, with a production per year between 121000 and 200000 egg-batches, used for different researches in field conditions, plants or insecticide testing. In this paper, authors collective present results obtained in laboratory conditions regarding egg batches productions, data concerning behaviour of the insects from different colonies in field conditions and data concerning behaviour of some maize hybrids to $O$. nubilalis attack, in field condition.

\section{MATERIALS AND METHODS}

$O$. nubilalis is grow in laboratory conditions, in continuous flux, on same artificial diet, at Plant Protection Collective in frame of the National Agricultural Research and Development Institute Fundulea, Calarasi County, Romania. For larvae stage, the growing conditions in laboratory are: air temperature $27-28{ }^{\circ} \mathrm{C}$ and air relative humidity between 60 and $90 \%$ (Fig. 1). The ventilation and light must be assigned all day. At the pupae stage, the growing conditions in laboratory are: air temperature between 21 and $25{ }^{\circ} \mathrm{C}$, air relative humidity between 60 and $90 \%$, permanent 
ventilation and continuous dark. At the moth stage, for favoring egg batches deposition, growing laboratory conditions must be similar with natural conditions from the field. In egg-batches deposition room, growing conditions are: for 18 hours air temperature $27-28{ }^{\circ} \mathrm{C}$ and 6 for hours, air temperature $20^{\circ} \mathrm{C}$ (simulation of the day-night alternation); air relative humidity between 82-85 $\%$ and permanent ventilation (Fig. 2). For mass rearing insects in laboratory conditions it has used diet with main ingredient, bean flour (Barbulescu A., 1980). Comparative with original formulation, now days, diet used for insects mass rearing are without "dried milk for calf's" ingredient (Tab. 1). At each generation in frame of each colony it has registered average number pupae/rearing box,

Tab. 1. Ingredients used for diet preparation for Ostrinia nubilalis $\mathrm{Hbn}$ insects mass rearing, quantity for 8 rearing boxes

\begin{tabular}{cc}
\hline Ingredient & Quantity \\
\hline Bean flour & $572 \mathrm{~g}$ \\
\hline Wheat bran & $160 \mathrm{~g}$ \\
\hline Beer yeast & $156 \mathrm{~g}$ \\
\hline Premix & $40 \mathrm{~g}$ \\
\hline Sugar & $155 \mathrm{~g}$ \\
\hline Ascorbic acid & $15,6 \mathrm{~g}$ \\
\hline Sorbic acid & $10 \mathrm{~g}$ \\
\hline Glacial acetic acid & $14,8 \mathrm{ml}$ \\
\hline Formaldehyde & $8,4 \mathrm{ml}$ \\
\hline Agar & $40 \mathrm{~g}$ \\
\hline Water & $3500 \mathrm{ml}$ \\
\hline
\end{tabular}

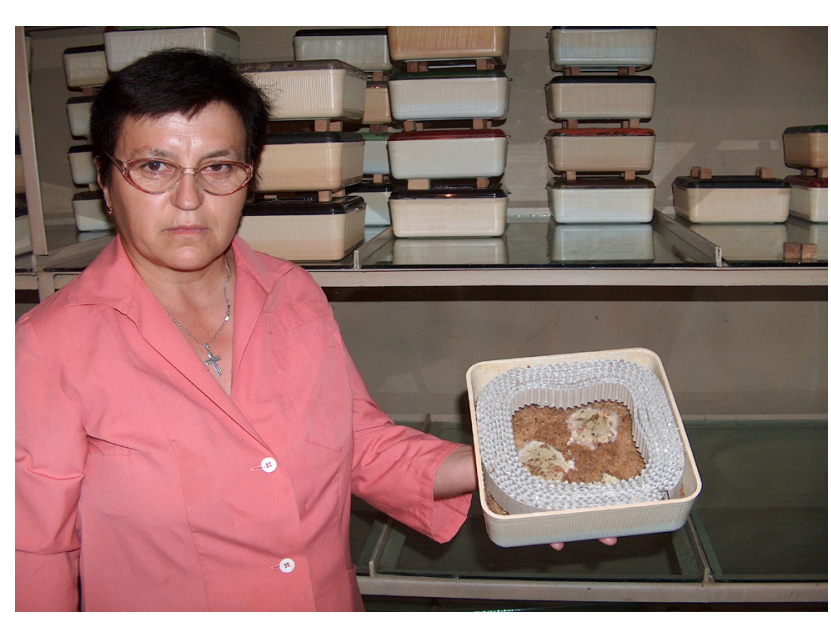

Fig. 1. Rearing chamber of Ostrinia nubilalis $\mathrm{Hbn}$ larva's, at NARDI Fundulea total number of the moths, female number and egg batches number.

Almost every year it has started a new insect's colony. At the end of maize vegetation period, larva's are harvested from the maize stalks. Until the spring, harvested larva's are stored in a place where air temperature is similar with environment temperature. In the spring, larva's are moved in laboratory where there will be transformed in pupae. In this way it has starting multiplication of a new insect colony, successive generations, in laboratory conditions. It has kept colonies created in last years, well as a reference colony, created in year 1979. For testing of the European corn borer insect colonies, starting in different years, for evaluation of the capacity of these insects for damaging maize plants, it has made artificial infestation in field conditions.

It has used one maize hybrid, considered sensitive of 0 . nubilalis attack. Also, in field conditions, at Plant Protection Collective it has tested maize hybrids, produced at NARDI Fundulea, both in natural and artificial infestation conditions. Egg batches produced in laboratory conditions in frame of Protection Collective it has used for testing maize inbreed lines tolerance at O. nubilalis attack, in frame of Maize and Sorghum Breeding Laboratory,

Maize plants were sowing at the last decade of the April. Plots length was of $10 \mathrm{~m}$, plots width was of 4,2 $\mathrm{m}$ ( 6 rows per plot). Distance between rows was of $70 \mathrm{~cm}$. Equivalent plant densities were of 50000 per hectare. Plots were arranged according randomized blocks scheme. With,

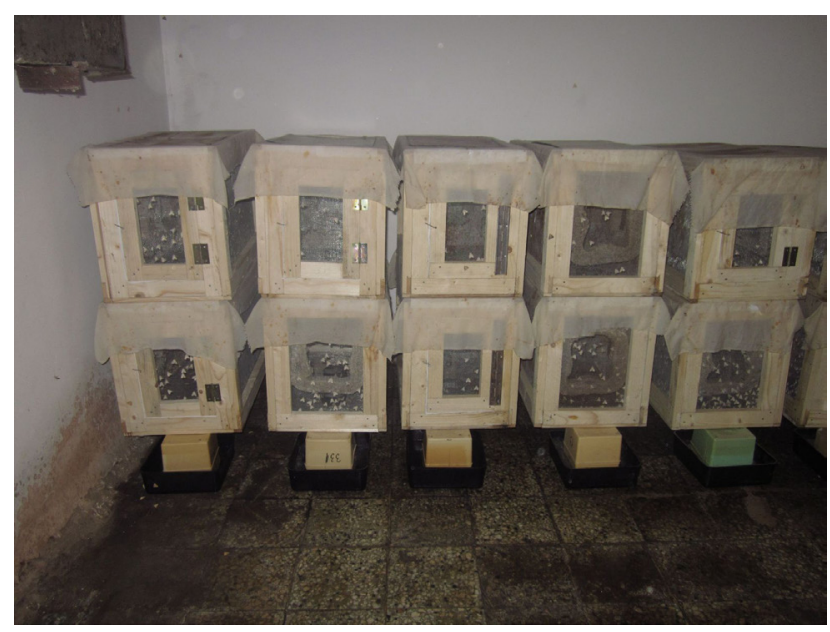

Fig. 2. Chamber of egg-batches deposition, at NARDI Fundulea 
appreciative 10 days before panicle emergence (end of the June or beginning of July), maize plants were infested with $10 \mathrm{egg}$ batches/plant, twice, 5-6 days, between infestations. Egg-batches used for artificial infestation are in "black-head" stage, when larva head become visible. Attack level of the European corn borer at the maize plants were analyzed in autumn (September) after the end of the maize vegetation period. From each plot it has taken 20 maize plants, the stalks was cooped in twice and it has determined three parameters: attack frequency, gallery length $(\mathrm{cm})$ and number of the alive larva/plant. The results were statistical analyzed through variance analysis, using ANOVA software.

\section{RESULTS AND DISCUSSION}

From 1975, at NARDI Fundulea it has rearing, O. nubilalis in continuous flux, on same artificial diet for obtaining of the egg batches used for artificial infestation of the maize plants, in field conditions. This is a better method to test maize lines and hybrids reaction to pest attack or testing effectiveness of both, chemical and biological methods to control this pest. The rearing activity in laboratory conditions has two distinct periods. First period, from Jully to March, when we maintain biological material from one month to another and second period, from March to July when biological material it has mass rearing, for obtain more then 100000 egg-batches used in different research themes, in period last decade of Junefirst decade of July. Data from table 2 demonstrate that between 2009 and 2013, in period March-July it has obtained a variable number of egg batches, between 109843 and 203253. Along the time, eggbatches number, obtained at the beginning of July, used for artificial infestations of the maize plants, ranged between 120000 and 135000 . But in some years, like in 2009, it has obtained less number of the egg batches. In some year, like 2010 it has obtained more then 200000 egg batches.

Total number of moths, obtained in laboratory conditions, in period March-July, ranged between 115112 and 150758 moths. Female percent has close values in all years taken in study, of $45 \%$. This data is in accordance with those obtained by Barbulescu (1993, 1996, 2001). Average number of the egg batches/female varied from one year to another. In 2010 it has registered highest value of this parameter $(3,0$ egg batches/female). One year early it has registered lowest alue of this parameter, from period taken in study. Generally, average number of the egg-batches/female, in period March-July ranged between 2,0 and 2,5. Number of rearing boxes used for mass rearing of the 0 . nubilalis, in period March-July, depends of the research plan. The highest number of rearing boxes used in last 5 years it has registered in 2010 (329 boxes). Generally, rearing box number, ranged between 240 and 300. In last years, average number of the pupae/rearing box ranged between 466 and 565.

Data from tables 3-5 show behavior of the insect colonies, created in different years, in field conditions. One maize hybrid was artificial infested with egg-batches, produced from different insect colonies, in laboratory conditions. Regard as average gallery length per plant, it hasn't registered higher difference of this parameter between recent insects colonies (2008, 2010 and 2011) and insect colony started from 1979 . Highest values of gallery length/plant it has registered in 2011, comparative with 2012 and 2013. A possible explication for this is because of favorable climatic conditions for insect development in 2011, especially in period of

Tab. 2. Data concerning mass rearing of the European corn borer (Ostrinia nubilalis $\mathrm{Hbn}$ ), in controlled laboratory conditions, în continuous flux, on the same artificial diet, period 2009-2013

\begin{tabular}{cccccc}
\hline Specification & 2009 & 2010 & 2011 & 2012 & 2013 \\
\hline Number of the rearing boxes & 248 & 329 & 260 & 286 & 243 \\
\hline Average number of the pupae/box & 565 & 505 & 486 & 466 & 524 \\
\hline Total number of the moths & 131041 & 150758 & 116342 & 134085 & 115112 \\
\hline Total number of the females & 59058 & 67922 & 52354 & 60338 & 51799 \\
\hline \% female & 45,07 & 45,05 & 45,00 & 45,00 & 45,01 \\
\hline Total number of the egg-batches & 109843 & 203253 & 136043 & 121945 & 133550 \\
\hline Average nr. egg-batches/female & 1,9 & 3,0 & 2,7 & 2,4 & 2,5 \\
\hline
\end{tabular}


larva eclosion and larva first stage. In 2011 gallery length/plant ranged between 30,0 and $36,1 \mathrm{~cm}$. In 2012, gallery length/plant ranged between 13,3 and 14,7 cm and in 2013 gallery length/plant ranged between 15,9 and $16,4 \mathrm{~cm}$.

Regard as average number of alive larva/plant, in 2011, data from table 3 show that this parameter ranged between 5,0 larvae/plant, in case of colony created in 1979 and 6,3 in case of the colony created in 2010. Differences between control variant and last two variants are statistically assigned $(\mathrm{P}<0,0001)$. In climatic conditions of years 2012 and 2013, average number of alive larvae/plant have lower values, comparative with 2011, and ranged between 1,3 and 1,8 (2012) and 1,9 and 2,2 (2013). In 2012, only in case of insect colony created in 2010, alive larvae/plant value is statistically assigned $(\mathrm{P}<0,001)$. In 2013 , the differences between insect colonies are not statistically assigned. All the data from period 2011-2013 demonstrate that even insects is rearing more then 440 generations in laboratory conditions, they don't lose capacity of producing damage at maize plants in field conditions and

Tab. 3. Behavior of the 0 . nubilalis Hbn colonies, starting in different years, in field conditions, year 2011

\begin{tabular}{ccccc}
\hline Colony & $\begin{array}{c}\text { Generation } \\
\text { number }\end{array}$ & $\begin{array}{c}\text { Attack } \\
\text { frequency }(\%)\end{array}$ & $\begin{array}{c}\text { Gallery length } \\
\text { (cm/plant) }\end{array}$ & $\begin{array}{c}\text { Alive larvae } \\
\text { (nr./plant) }\end{array}$ \\
\hline $1979(\mathrm{mt})$ & 413 & 100 & 33,8 & 5,0 \\
\hline 2008 & 48 & 100 & $30,0 \mathrm{o}$ & $5,7^{* *}$ \\
\hline 2010 & 22 & 100 & 33,4 & $6,3^{* * *}$ \\
\hline 2011 & 9 & 100 & 36,1 & $6,0 * *$ \\
\hline & & $\mathrm{LSD}_{5 \%}=3,04$ & $\mathrm{LSD}_{5 \%}=0,40$ \\
& & & $\operatorname{LSD}_{1 \%}=4,26$ & $\mathrm{LSD}_{1 \%}=0,55$ \\
& & & $\operatorname{LSD}_{0,1 \%}=6,17$ & $\mathrm{LSD}_{0,1 \%}=0,80$
\end{tabular}

Tab. 4. Behavior of the $O$. nubilalis Hbn colonies, starting in different years, in field conditions, year 2012

\begin{tabular}{ccccc}
\hline Colony & $\begin{array}{c}\text { Generation } \\
\text { number }\end{array}$ & $\begin{array}{c}\text { Attack } \\
\text { frequency }(\%)\end{array}$ & $\begin{array}{c}\text { Gallery length } \\
\text { (cm/plant) }\end{array}$ & $\begin{array}{c}\text { Alive larvae } \\
\text { (nr. } / \text { plant })\end{array}$ \\
\hline $1979(\mathrm{mt})$ & 425 & 100 & 13,3 & 1,3 \\
\hline 2008 & 59 & 100 & $14,1^{*}$ & 1,5 \\
\hline 2010 & 33 & 100 & $14,7^{* * *}$ & $1,8 * *$ \\
\hline 2011 & 20 & 100 & 13,7 & 1,3 \\
\hline & & $\operatorname{LSD}_{5 \%}=0,46$ & $\operatorname{LSD}_{5 \%}=0,31$ \\
& & $\operatorname{LSD}_{1 \%}=0,64$ & $\operatorname{LSD}_{1 \%}=0,43$ \\
& & & $\operatorname{LSD}_{0,1 \%}=0,93$ & $\operatorname{LSD}_{0,1 \%}=0,63$
\end{tabular}

Tab. 5. Behavior of the 0 . nubilalis Hbn colonies, starting in different years, in field conditions, year 2013

\begin{tabular}{ccccc}
\hline Colony & $\begin{array}{c}\text { Generation } \\
\text { number }\end{array}$ & $\begin{array}{c}\text { Attack } \\
\text { frequency }(\%)\end{array}$ & $\begin{array}{c}\text { Gallery length } \\
\text { (cm/plant) }\end{array}$ & $\begin{array}{c}\text { Alive larvae } \\
\text { (nr. } / \text { plant })\end{array}$ \\
\hline $1979(\mathrm{mt})$ & 442 & 100 & 15,9 & 1,9 \\
\hline 2008 & 77 & 100 & 16,2 & 2,0 \\
\hline 2010 & 51 & 100 & 16,1 & 2,2 \\
\hline 2011 & 38 & 100 & 16,4 & 2.2 \\
\hline & & $\operatorname{LSD}_{5 \%}=0,91$ & $\operatorname{LSD}_{5 \%}=0,41$ \\
& & $\operatorname{LSD}_{1 \%}=1,28$ & $\operatorname{LSD}_{1 \%}=0,57$ \\
& & & & $\operatorname{LSD}_{0,1 \%}=1,85$ \\
& & & &
\end{tabular}


they can be used for artificial infestation of the maize plants, in frame of the different research themes.

At the end of the year 2013 the insect colony created in 1979 arrived at 442th consecutive generation, the insect colony created in 2008 arrived at 77th consecutive generation, insect colony created in 2010 arrived at 51rd consecutive generation, while insect colony created in 2011 arrived at 38nd consecutive generation.

Every year, at experimental field of the Plant Protection Collective, there wre tested maize hybrids produced at NARDI Fundulea, in conditions of artificial infestation with European corn borer ( $O$. nubilalis) egg-batches, produced in laboratory conditions. In this paper are present some result from field testing trials, between 2011 and 2013. Data from Fig. 3 show that, in climatic conditions of the year 2011, attack frequency was of $95 \%$ in most of the cases, except hybrid Crisana with attack frequency of $80 \%$ and Iezer with attack frequency of $100 \%$. In condition of the year 2012, at plants artificial infested with ECB egg batches, attack frequency present lower values comparative with 2011, except variants Danubian and Crisana. Attack frequency at the maize hybrids taken in study, ranged between 85 and $100 \%$, in climatic conditions of the year 2013 , except hybrids F 475 M (F=65 \%) and Iezer (80 $\%)$.

Data from table 6 show that attack intensity of the 0 . nubilalis at maize plants, in conditions of artificial infestation where higher in 2011 comparative with years 2012 and 2013, especially because of the climatic conditions from the end of June, favorable for larva development, from emergence until they enter in plant stalks. Regard average gallery length/plant, in 2011, higher values of this parameter registered at hybrids Rapsodia, Danubian and Generos while lowest values registered at hybrids Olt and Mostistea. At new hybrids, Iezer and Crisana, average gallery length/plant, as result of the larva attack, has lower values, 10,3 and 10,0 cm. Regard as alive number of larvae/plant, in climatic conditions of the year 2011, higher values of this parameter were meet at hybrids Generos and Danubian. At hybrids Rapsodia, Paltin and F 376 it has registered more then 3 larvae/plant. Lowest value of this parameter, in conditions of artificial infestation of the maize plants has registered in case of Mostistea hybrid (2,0 alive larvae/plant). In climatic conditions of the year 2012, average gallery length/plant has lower values comparative with 2011. However at hybrids Generos and Danubian it has registered higher values of this parameter, close to values

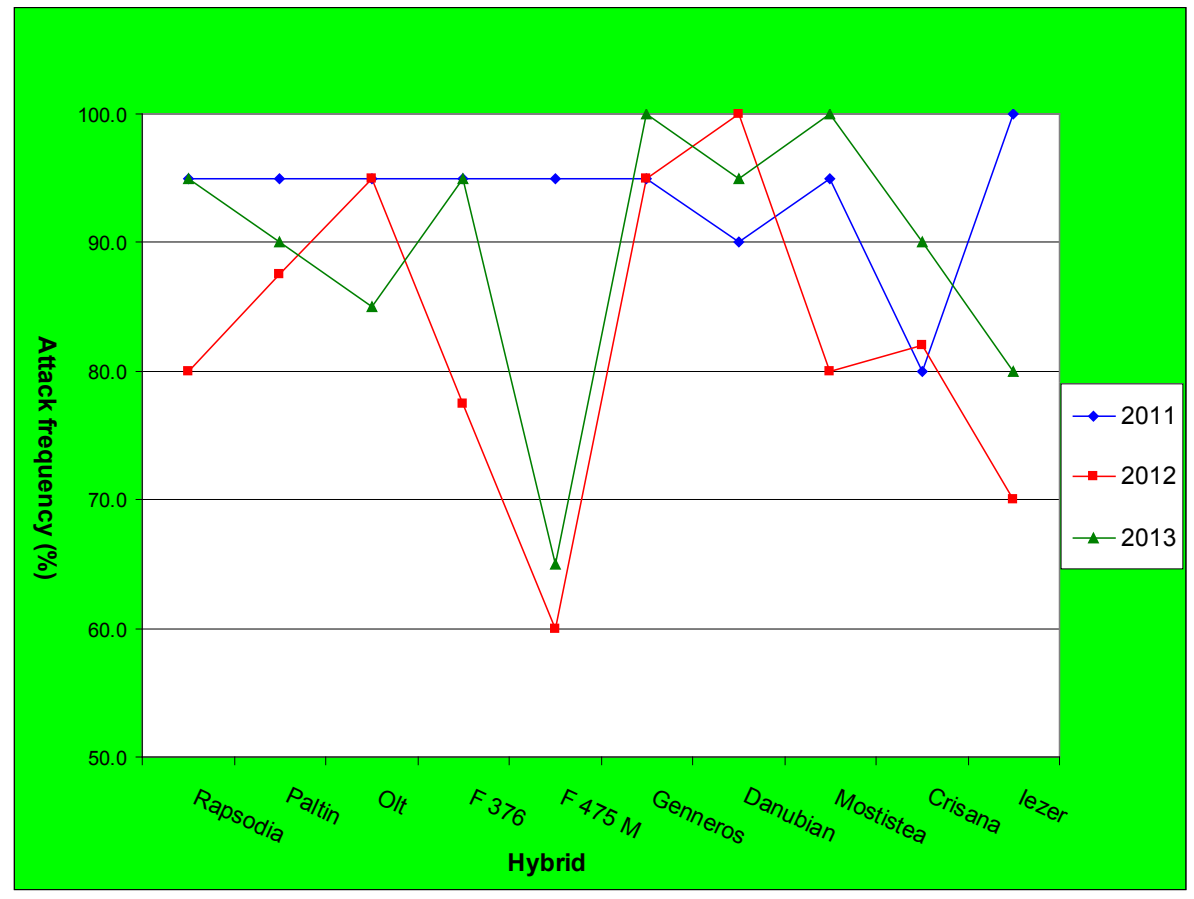

Fig. 3. Behaviour of the maize hybrids to Ostrinia nubilalis Hbn attack, at NARDI Fundulea, period 2011-2013 
Tab. 6. Behavior of maize hybrids assortment at attack of the 0 . nubilalis, at NARDI Fundulea (20112013), in conditions of artificial infestation

\begin{tabular}{|c|c|c|c|c|c|c|}
\hline \multirow[b]{2}{*}{ Hybrid } & \multicolumn{2}{|c|}{2011} & \multicolumn{2}{|c|}{2012} & \multicolumn{2}{|c|}{2013} \\
\hline & $\begin{array}{l}\text { Gallery length } \\
\text { (cm/plant })\end{array}$ & $\begin{array}{l}\text { Alive larvae } \\
\text { (nr./plant) }\end{array}$ & $\begin{array}{c}\text { Gallery } \\
\text { length }(\mathrm{cm} / \\
\text { plant })\end{array}$ & $\begin{array}{c}\text { Alive larvae } \\
\text { (nr./plant) }\end{array}$ & $\begin{array}{c}\text { Gallery } \\
\text { length }(\mathrm{cm} / \\
\text { plant })\end{array}$ & $\begin{array}{c}\text { Alive larvae } \\
\text { (nr./plant) }\end{array}$ \\
\hline Rapsodia (mt) & 19,9 & 3,2 & 13,0 & 2,6 & 10,1 & 1,9 \\
\hline Paltin & 14,9 으응 & 3,2 & 10,2 으므 & 2,5 & 10,7 & 2,1 \\
\hline Olt & 9,3oㅡㅁㅡ & 2,0 으음 & 2,6 으o & 0,6 ㅇo으 & $6,9 \underline{900} \underline{0}$ & 1,4 \\
\hline F 376 & 13,0 으응 & 3,1 & $8,6 \underline{6000}$ & 2,8 & 9,1 & 1,5 \\
\hline $\mathrm{F} 475 \mathrm{M}$ & 11,6 으o음 & 2,1 ㅇo응 & 7,3 ooo & 0,7 ㅇo으 & 3,8 ㅇo으 & 0,4 으o 0 \\
\hline Genneros & 20,2 & $4,1 * *$ & $16,2^{* *}$ & $3,6^{* * *}$ & 10,0 & 2,3 \\
\hline Danubian & 19,7 & $4,2^{* *}$ & $15,2^{* *}$ & 2,5 & 8,8 & 1,4 \\
\hline Mostistea & 9,3 oㅡo & 2,0 ㅇo으 & 6,1 ㅇo음 & $1,60 \underline{0} \underline{0}$ & 9,7 & 1,7 \\
\hline Crisana & 10,3 oo으 & 2,3 oㅡ & 5,6 oo음 & 1,0 ㅇo으 & $6,5 \underline{50} \underline{0} \underline{0}$ & $0,9 \underline{9} \underline{0} \underline{0}$ \\
\hline \multirow[t]{2}{*}{ Iezer } & 10,0 으응 & 2,8 & 3,4 으o & 0,5 oㅡo & 4,7 ㅇo응 & 0,9 oo으 \\
\hline & $\begin{array}{l}\operatorname{LSD}_{5 \%}=1,34 \\
\operatorname{LSD}_{1 \%}=1,80 \\
\operatorname{LSD}_{0,1 \%}=2,35\end{array}$ & $\begin{array}{c}\operatorname{LSD}_{5 \%}=0,63 \\
\operatorname{LSD}_{1 \%}=0,84 \\
\operatorname{LSD}_{0,1 \%}=1,10\end{array}$ & $\begin{array}{c}\operatorname{LSD}_{5 \%}=0,80 \\
\operatorname{LSD}_{1 \%}=1,07 \\
\operatorname{LSD}_{0,1 \%}=1,40\end{array}$ & $\begin{aligned} \operatorname{LSD}_{5 \%} & =0,43 \\
\operatorname{LSD}_{1 \%} & =0,58 \\
\operatorname{LSD}_{0,1 \%} & =0,76\end{aligned}$ & $\begin{array}{c}\operatorname{LSD}_{5 \%}=1,23 \\
\operatorname{LSD}_{1 \%}=1,65 \\
\operatorname{LSD}_{0,1 \%}=2,16\end{array}$ & $\begin{aligned} \mathrm{LSD}_{5 \%} & =0,51 \\
\mathrm{LSD}_{1 \%} & =0,68 \\
\mathrm{LSD}_{0,1 \%} & =0,89\end{aligned}$ \\
\hline
\end{tabular}

from 2011. Lowest values of gallery length/plant, from the experiment, have registered in case of Olt, Iezer and Crisana hybrids. Also, at hybrid Generos, in 2012, it has registered higher number of alive larvae/plant, from the experiment, while at hybrids Olt, F $475 \mathrm{M}$ and Iezer this values were subunit. In climatic conditions of the year 2013, average gallery length/plant has slightly higher values comparative with 2012, at Iezer, Crisana, Mostistea, F 376 or Paltin hybrids and lower values comparative with previous year at Rapsodia, F 475 M, Generos and Danubian hybrids. Regard as alive larvae/plant, lowest value of this parameter it has registered in case of F $475 \mathrm{M} \mathrm{(0,4} \mathrm{larvae/plant).}$ Also at hybrids Iezer and Crisana it has registered less then one larva/plant. At hybrids Paltin and Generos, in climatic conditions of the year 2013, it has registered higher attack intensity of $O$. nubilalis, at maize plat artificial infested.

At experimental field of the Maize and Sorghum breeding laboratory, between 2010 and 2012 it has tested 250 inbreed maize lines, both in conditions of natural and artificial infestation of the maize plants, with $O$. nubilalis egg-batches, produced in laboratory conditions.

From 250 inbreed lines, 67 were partially or total resistant to ECB attack and were keep in maize breeding process. The cooperation between Plant Protection Collective and Maize and Sorghum

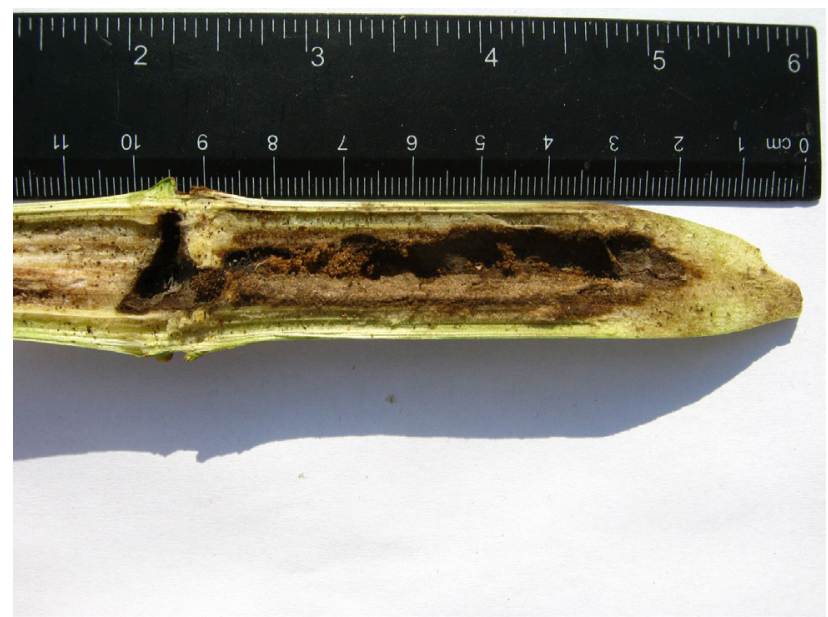

Fig. 4. Gallery of $O$. nubilalis larva in maize stalk

breeding laboratory materialized in maize hybrids breeding with different degree of resistance to $O$. nubilalis attack.

\section{CONCLUSION}

Rearing of the European corn borer (Ostrinia nubilalis $\mathrm{Hbn}$ ) in laboratory conditions, in continuous flux, on same artificial diet, is a good method for mass production of the insect's egg-batches, necessary for the field research concerning maize hybrids and lines tolerance at pest attack or researches concerning biological or chemical control of this pest. 
Between 2009 and 2013, in period March-July it has obtained a variable number of egg-batches, between 109843 and 203253 used for artificial infestations of the maize plants, in field conditions.

The average number of the egg-batches/ female obtained in laboratory conditions was 1,9 in year 2009, 3,0 in year 2010, 2,7 in year 2011, 2,4 in year 2012 and 2,5 in year 2013 .

At the end of the year 2013 the insect colony created in 1979 arrived at 442nd consecutive generation, the insect colony created in 2008 arrived at 77 th consecutive generation, the insect colony created in 2010 arrived at 51st consecutive generation, while the insect colony created in 2011 arrived at 38th consecutive generation.

Even insects is rearing more then 440 generations in laboratory conditions, they don't lose capacity of producing damage at maize plants in field conditions.

Climatic conditions from summer period, at NARDI Fudulea, between 2011 and 2013 were variable. Climatic conditions of year 2011 were most favorable for European corn borer attack and the maize hybrids reaction to this pest, both in natural and artificial infestation conditions were better differentiated.

Between 2011 and 2013, in conditions of artificial infestation of the maize plants with $O$. nubilalis egg-batches, higher attack of the pest it has registered at hybrids Danubian, Generos, Rapsodia while lower attack of the pest it has registered in case of the Olt hybrid.

Good results concerning tolerance at $O$. nubilalis attack, it has registered in case of new maize hybrids, produced at NARDI Fundulea.

From 250 inbreed lines tested in experimental field of the Maize and Sorghum breeding laboratory, 67 were partially or total resistant to European corn borer attack and were keep in maize breeding process.

\section{REFERENCES}

1. Alexandri A (2011). Ostrinia nubilalis-Diabrotica virgifera virgifera. Plants Health 159:12.

2. Barbulescu A (1977). Rearing of the European corn borer Ostrinia nubilalis Hbn. on different artificial diets. Problems of Plant Protection 5(2):141-150.

3. Barbulescu A (1979). Influence of the temperature concerning European corn borer egg incubation Ostrinia nubilalis Hb. Problems of Plant Protection 7(4):377-384.
4. Barbulescu A (1980). Techniques of mass rearing on artificial diet of the European corn borer (Ostrinia nubilalis Hbn.). Problems of Plant Protection 8(1):1-12.

5. Barbulescu A (1984). Behavior of the European corn borer (Ostrinia nubilalis) reared a different number of successive generations on same artificial diet. Problems of Plant Protection (12)4: 285-290.

6. Barbulescu A (1986). Results concerning mass rearing of the European corn borer Ostrinia nubilalis on same diet successive generations. Annals of NARDI Fundulea 53:373-381.

7. Barbulescu A (1993). Data obtained in period 1985-1989 concerning rearing of the specie Ostrinia nubilalis on artificial diet many successive generations. Problems of Plant Protection 21(1):1-11.

8. Barbulescu A (1996). Data obtained in period 1990-1992 concerning rearing of the specie Ostrinia nubilalis on artificial diet many successive generations.Problems of Plant Protection 24(1):1-12.

9. Barbulescu A (2001). Data obtained in period 1996-1998 concerning rearing of the specie Ostrinia nubilalis on artificial diet many successive generations. Problems of Plant Protection 29(1):33-40.

10. Barbulescu A, Cosmin O (1997). Maize inbreed lines obtained at Fundulea, characterized by a certain resistance degree to Ostrinia nubilalis $\mathrm{Hb}$. Problems of Plant Protection 25(1):1-8.

11. Barbulescu A, Cosmin O, Sabău I (1999). Data obtained at Fundulea, concerning maize resistance at European corn borer Ostrinia nubilalis attack. Problems of Plant Protection 27 (2):173-180.

12. Barbulescu A, Popov, Sabău I (2001). The behavior of a Monsanto maize hybrid-Dekalb 512 bt to the attack by the European corn borer in Romania. Romanian Agricultural Research 15: 65-73.

13. Cristea M, Cabulea I, Sarca T (2004). Maize. Monographic study. Romanian Academy Publishing house 14(1):589626.

14. Beres KP, Konefal T (2010). Distribution range of the European Corn Borer (Ostrinia nubilalis $\mathrm{Hbn}$ ) on maize in 2004-2008 in Poland. Journal of Plant Protection Research 50(3): 326-334.

15. Beres KP (2012). Flight dynamics of Ostrinia nubilalis Hbn. (Lep., Crambidae) based on the light and pheromone trap catches in Nienadowka (south-eastern Poland) in 20062008. Journal of Plant Protection Research 52(1):131138.

16. Brookes G (2007). The benefits of adopting genetically modified, insect resistant (Bt) maize in the European Union (EU): first results from 1998-2006 plantings, PG Economics Ltd:1-39.

17. Brookes G (2008). The impact of using GM insect resistant maize in Europe since 1998. International Journal of Biotechnology 10(2-3):148-166.

18. Derron JO, Goy G, Breitenmoser S (2009). Remove from marked Records Biological characterisation of the bivoltine race of the European corn borer (Ostrinia 
nubilalis) in the Lake Geneva region. Revue Suisse d'Agriculture 41(3):179-184.

19. Gathmann A, Rothmeier I (2005). Dispersal of the European Corn Borer (Ostrinia nubilalis Hbn.) in southern Rhineland - Results of the infestation assessment 2002 and 2003. Journal of Plant Diseases and Protection 112(2):200-203.

20. Ivas AD, Muresanu F (2011). The abundance and dynamics of lepidoptera pests from maize, soybean, sugar beet crops, in conditions of Agricultural Research and Development Station Turda. Bulletin UASMV Agriculture 68 (1):438-444.

21. Keszthelyi S (2010). Flight dynamics analysis of the European corn borer (Ostrinia nubilalis (Hübner)) populations in Hungary from the second part of the twentieth century until the present. Archives of Phytopathology And Plant Protection 1286-1294.

22. Kocmánková E, Trnka $M$, Eitzinger J, Formayer $H$, Dubrovsky M, Semerádová D, Zalud Z, Juroch J, Mozny M (2010). Estimating the impact of climate change on the occurrence of selected pests in the Central European region. Climate Research 44: 95-105.

23. Korycinska A, Cannon R (2010). Rapid assessment of the need for a detailed Pest Risk Analysis for Ostrinia nubilalis, European corn borer. The Food and Environment Research Agency 1-6.
24. Malschi D, Muresan F, Ivas A (2013). Evaluation of pests potential from field crops in the Transylvanian plain. Annals N.A.R.D.I. Fundulea 81:165-183.

25. Muresan F, Mustea D (1995). Results obtained in control of the European corn borer-Ostrinia nubilalis $\mathrm{Hbn}$. at SCDA Turda. Problems of Plant Protection 23(1): 23-34.

26. Mustea D (1977). Effectiveness of some insecticides for Europan corn borer (Ostrinia nubilalis Hbn.) controll. Problems of Plant Protection 5(2):163-172.

27. Mustea D (1981). Elemments of damages estimation produced by European corn borer, Ostrinia nubilalis $\mathrm{Hbn}$. at maize crops. Problems of Plant Protection 9(4):349358.

28. Mustea D (1990). Study of some maize resistance aspects at Ostrinia nubilalis $\mathrm{Hbn}$. In recurrent selection process. ProblemS of Theoretical and Applied Genetics 22(2):6171.

29. Popov C, Barbulescu A (2007). 50 years of scientific activity in domain of field crop protections, against diseases and pests. Annals of N.A.R.D.I. Fundulea 75:371-404.

30. Popov C, Roşca I (2007). Technology of European corn borer (Ostrinia nubilalis $\mathrm{Hbn}$.) mass rearing, in continuous system and successive generations. Entomological Research 37(1):126. 